\title{
THE USE OF BIOFILTRATION PROCESS TO REMOVE ORGANIC MATTER FROM GROUNDWATER
}

\author{
Dorota Papciak', Jadwiga Kaleta', Alicja Puszkarewicz'1, Barbara Tchórzewska-Cieślak² \\ 1 Department of Water Purification and Protection, Rzeszów University of Technology, Faculty of Civil and \\ Environmental Engineering and Architecture, Aleja Powstańców Warszawy 6, 35-959 Rzeszów, Poland, \\ e-mail:dpapciak@prz.edu.pl, jkaleta@prz.edu.pl, apuszkar@prz.edu.pl \\ 2 Department of Water Supply and Sewage Systems, Rzeszów University of Technology, Faculty of Civil and \\ Environmental Engineering and Architecture, Aleja Powstańców Warszawy 6, 35-959 Rzeszów, Poland, \\ e-mail: cbarbara@prz.edu.pl
}

Received: 2016.03.16

Accepted: 2016.06.01 Published: 2016.07.01

\begin{abstract}
The article describes the research on the removal of organic matter from natural underground water using biofiltration process. The study was carried out in semi-technical scale on a model filter composed of activated carbon WD-extra. The development of biological activity in a biosorption bed, as well as observations on the relationship between the processes of sorption and biodegradation was evaluated based on the Eberhardt, Madsen, Sontheimer (EMS) test. Leading operation control parameters of biologically active carbon filter BAF included: change of TOC content, dissolved oxygen and permanganate index. To evaluate the colonization of granular carbon determination of ATP value was used. The presence of the biofilm was found by observation using light and scanning microscopes. The organic compounds in the water taken were adsorbed $100 \%$ and $70 \%$ biodegradable. The combination of sorption process with biodegradation until depletion of activated carbon adsorption capacity allowed in the initial phase of coalbed work for the removal of organic matter in approx. $100 \%$. Formation of biofilm at the right time allowed to extend the filtration cycle and helped lower the TOC by $70 \%$, i.e. from $10 \mathrm{mg} \mathrm{C} / 1$ to $3-4 \mathrm{mg} \mathrm{C} / 1$.
\end{abstract}

Keywords: groundwater, biofiltration process, total organic carbon, water treatment.

\section{INTRODUCTION}

The presence of natural organic matter in waters utilized for communal purposes is a problem faced by many treatment plants. The quality of underground water depends on the circulation of geochemical and biological materials, soil properties, mobility of elements, biological sorption, and can be modified by anthropogenic activity [Pisarek i Głowacki 2015]. In many cases, technological systems have to be extended with coagulation, chemical oxidation, sorption on active carbons, or sorption combined with biodegradation [Kaleta and Elektorowicz, 2009; Krupińska, 2012]. Due to the level of water pollution and the imperfection of applied processes, sorption and biodegradation on active carbons have become necessary supplements to water purification systems. Initially, active carbon was used as a sorbent, and for over twenty years as a biological filing for active carbon beds.

In classic biological beds, the processes of removal of dissolved impurities take place only by means biochemical and assimilation processes, involving biological membrane, but without a carrier. In biosorption beds the carrier - the biofilter filling - plays a special role, depending on its characteristics - it may serve as an adsorbent, molecular sieve, ion exchanger and a substance for nutrition and buffering the biochemical reaction of the environment [Papciak 2007]. What is important is not only its granulation or actual sur- 
face, but also its capability for producing stable connections between it and the microorganisms [Papciak et al 2013, Papciak 2013]. When choosing the biofilter filling, its price is taken into account as much as its effectiveness. Presently, the most commonly used, and thus the most researched, are carbon beds [Wilmański and Gancarz 1997, Matuszewski et al 1999, Wolborska et al 2003, Kiedryńska 2004, Pruss at al 2009]. The effectiveness of biologically active carbon filters in removal of various impurities is very high. Due to susceptibility to decomposition and capability for adsorption on carbon, the organic substances brought to the filter can be divided into four groups [Papciak et al 2011]:

- non-adsorbent substances - not subject to biodegradation,

- non-adsorbent substances - subject to biodegradation,

- adsorbent substances - not subject to biodegradation,

- adsorbent substances - subject to biodegradation.

The substances in the first group cannot be removed from water by filtration in carbon beds. The second group substances are removed during travel through carbon filter, and the third and fourth group can be eliminated in the filter. Many micro-impurities are very hard to remove in conventional processes, applied in water-treatment technology. This is why attempts are made to develop a biosorption filter, based on WD-extra granulated active carbon, in order to test the possibilities of creating a biofilm and determining the level of biodegradability of the organic matter present in water.

\section{METHODS}

The research was conducted at semi-technical scale, on a model filter with gravitational flow, filled with an active WD-extra carbon bed. Biofilter working parameters:

- carbon deposit height: $H=1.12 \mathrm{~m}$;

- diameter: $D=55 \mathrm{~mm}$;

- filtration speed: $v=3-2 \mathrm{~m} / \mathrm{h}$

- analyzed duration of work: 8 months.

The biofilter was supplied with natural underground water, with parameters described in Table1. The underground water fed to the filter was previously purified in a technological system: aeration - chemical oxidation - coagulation - sedimentation - filtration by a two-layer bed (quartz sand - anthracite).

The analysis was performed for the incoming water and for the post-biofiltration process water. The following water parameters were controlled:

- Total Organic Carbon (TOC) content - with organic carbon analyzer Sievers 53100C (once a week).

- Oxygen content - with a Hach-Lange oxygen probe, in accordance to device instruction manual, with special attention to choice of

Table 1. Physicochemical parameters of the bio-filtered water

\begin{tabular}{|c|c|c|c|c|}
\hline \multirow{2}{*}{ Parameter } & \multirow{2}{*}{ Unit } & \multirow{2}{*}{$\begin{array}{l}\text { Value required for } \\
\text { drinking water }\end{array}$} & \multicolumn{2}{|c|}{ The range of values } \\
\hline & & & Untreated water & Treated water \\
\hline Color & Hazen & acceptable & $40-100$ & $10-16$ \\
\hline Turbidity & NTU & 1.0 & $8.0-14.0$ & 1 \\
\hline $\mathrm{pH}$ & - & $6.5-9.5$ & $6.4-7.0$ & $7.8-8.1$ \\
\hline Temperature & ${ }^{\circ} \mathrm{C}$ & - & $10.8-12.1$ & - \\
\hline Total hardness & $\begin{array}{c}\mathrm{val} / \mathrm{m}^{3} \\
\mathrm{gCaCO}_{3} / \mathrm{m}^{3}\end{array}$ & $\begin{array}{l}1.2-10.0 \\
60-500\end{array}$ & $\begin{array}{c}4.0-9.4 \\
200-470\end{array}$ & $280-380$ \\
\hline Sulfates & $\mathrm{gSO}_{4}{ }^{2-} / \mathrm{m}^{3}$ & 250 & $60-240$ & $60-124$ \\
\hline Conductivity & $\mathrm{mS} / \mathrm{cm}$ & - & $430-1016$ & $648-891$ \\
\hline Alkalinity & $\mathrm{val} / \mathrm{m}^{3}$ & - & $2.5-4.5$ & - \\
\hline Iron & $\mathrm{gFe} / \mathrm{m}^{3}$ & 0.2 & $14.0-44.0$ & $<0.02$ \\
\hline Manganese & $\mathrm{gMn} / \mathrm{m}^{3}$ & 0.05 & $0.74-2.58$ & $<0.02$ \\
\hline Ammonium & $\mathrm{gNH}_{4}^{+} / \mathrm{m}^{3}$ & 0.5 & $1.20-1.98$ & $0.09-0.28$ \\
\hline Permanganate index & $\mathrm{gO}_{2} / \mathrm{m}^{3}$ & 5.0 & $11.0-18.1$ & $4.7-5.0$ \\
\hline Total Organic Carbon (TOC) & $\mathrm{gC} / \mathrm{m}^{3}$ & no abnormal change & 11.0-20.0 & $7.0-16.8$ \\
\hline Humic substances & $\mathrm{g} / \mathrm{m}^{3}$ & - & $6.5-14.0$ & $2.2-3.0$ \\
\hline
\end{tabular}


samples, so as to avoid water oxygenation (once a week after 3 months of biofilter operation).

- Permanganate index in accordance with PNEN ISO 8467:2001 (once a week).

- Total number of bacteria in accordance with PN-EN ISO 6222:2002 (once a week after 3 months of biofilter operation).

The development of activity inside the biosorption bed and the observations regarding the relationships between the sorption and biodegradation processes were evaluated based on the Eberhardt, Madsen, Sontheimer (EMS) test. ATP (adenosine triphosphate) determination was used for the evaluation of the settlement of granulated carbon, whose content is proportional to the number of microorganisms. The presence of the biofilm was confirmed by observation, using a light microscope and an electron scanning microscope JOEL SEM 5500 LV.

\section{Evaluation of work of model filter - test EMS}

The development of activity within biosorption beds, and the observations regarding the relationships between sorption and biodegradation processes, were recorded based on the Eberhardt, Madsen, Sontheimer (EMS) test [Wolborska and Cyran 2004,. The EMS test is based on the value of the indicator, described by the relation between the change in COD or permanganate index and the loss of dissolved oxygen, taking place during filtration.

$$
S=\frac{\Delta C h Z T}{\Delta O_{2}}
$$

where: $\Delta$ ChZT - loss of COD (with $\mathrm{K}_{2} \mathrm{Cr}_{2} \mathrm{O}_{7}$ or with $\mathrm{KMnO}_{4}$ )

$\Delta \mathrm{O}_{2}-$ loss of dissolved oxygen,

when $S=1-$ adsorption and biodegradation happen with identical intensiveness,

$S>1$ - adsorption dominates,

$S<1$ - biodegradation dominates,

$S=0, \Delta C h Z T=0, \Delta \mathrm{O}_{2}>0-$ sorption and biodegradation processes stopped,

$S$ undetermined, $\triangle \mathrm{ChZT}>0, \Delta \mathrm{O}_{2}=0-$ sorption present, biodegradation absent, $\triangle \mathrm{ChZT}=0, \Delta \mathrm{O}_{2}=0$ - sorption and biodegradation absent.

\section{Evaluation of effectiveness of GAC settlement by microorganisms}

ATP content determination was used for the evaluation of settlement of granulated carbon. Methodology was based on photometric measurement of bioluminescence in accordance with standard curve after ATP extraction. The bioluminescence readings, obtained in RLU units were finally calculated for the cATP content stated in picograms, proportionally to the activity of luminase used and the quantity of filtered sample. Assuming that one cell contains $10^{-16} \mathrm{~g}$ ATP, with $1 \mathrm{ng}$ of ATP being equal to a 1000 bacteria cells, the number of microorganisms in a determined sample was calculated [Aqua-tools Script, Siebel et al 2008]. For this purpose, $10 \mathrm{~g}$ of coal deposit was taken from the bottom part of the biofilter and shaken from $90 \mathrm{ml}$ of Ringer fluid for about 3 min. This extract was used for ATP analysis with procedures recommended by the manufacturer of Quench - Gone Aqueous (QGA) set.

\section{RESULTS AND DISCUSSION}

The tested water did not meet the sanitary requirements in terms of turbidity, color, oxidisability, ammonium ion, iron and manganese content. The high water color, correlating with above-norm oxidisability and the content of humus substances indicate the presence of natural organic matter in the water, which may appear in complex connections with manganese and iron compounds. In the subject water, large, seldom found in communal water intakes quantities of iron were found. Due to general hardness, the intake water is considered averagely hard, with $48-65 \%$ of the hardness being carbonate hardness. The raw water is also characterized by high sulphates concentration. The physicochemical composition of water intake points to possible issues in the process of its treatment. The existing water treatment station is very effective in removing iron and manganese. Only trace quantities of those elements may be found in the treated water. On the other hand, the color parameter is kept on a 10-15 Hazen level, with permissible quantity of 15 Hazen. In the discussed example, the color was influenced by organic substances - the TOC content in water was $7-12 \mathrm{mgC} / \mathrm{dm}^{3}$, over recommended content of $5 \mathrm{mgC} / \mathrm{dm}^{3}$. The actions taken towards more effective decreasing of their content by using the 
process of second-level filtration through a filter, filled with granulated active carbon, turned out to be successful. The TOC content at the outlet of the filter, in a period of six months (184 days), was within the range of $0-1 \mathrm{mg} / \mathrm{l}$ (Figure 1).

From the $170^{\text {th }}$ day of filter operation, the TOC content after filtration process was increased to about $3 \mathrm{mg} \mathrm{C} / \mathrm{l}$. For the next two months of filter operation, the TOC content of the filtered water stabilized at the level of $3-4 \mathrm{mgC} / 1$. This was still a value lower than $5 \mathrm{mgC} / 1$ - recommended by Ministry of Health and lower than presently obtained in water treatment plants. Removal of organic matter causes a growth in the biological stability of water. However, there are no unambiguous criteria, and the border concentrations of nutrients depend on the type of microorganisms and the type and concentration of the disinfectant used. It is thought that the biological stability of water is decided by the presence of assimilable organic carbon AOC and biodegradable

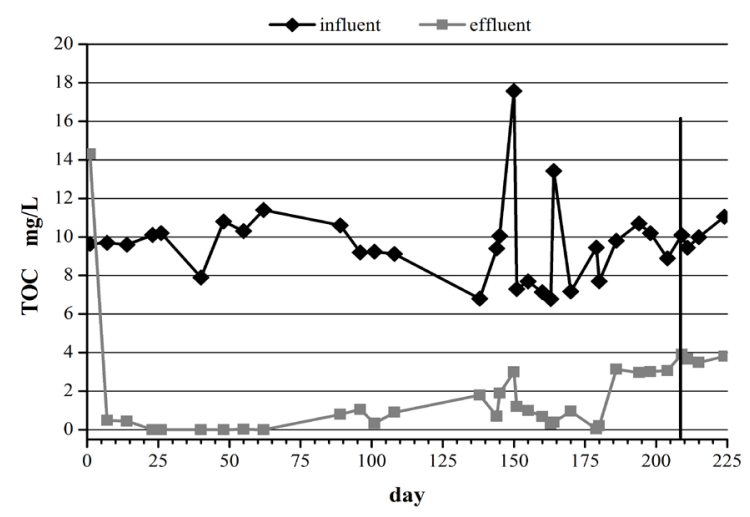

Figure 1. Changes in organic matter content in water subjected to biofiltration process on model filter (vertical line marks biofilter rinsing)

a)

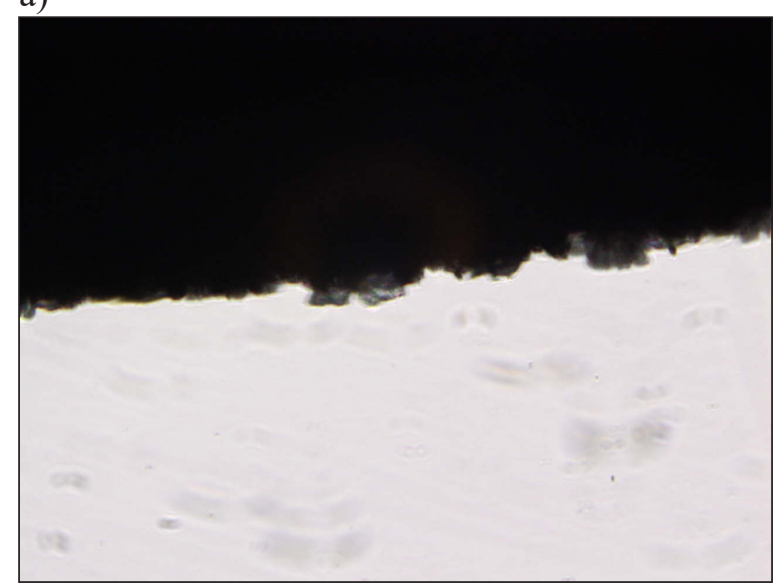

dissolved organic carbon BDOC, the content of nitrogen and phosphorus. In the case of AOC its content should not be over $0,15 \mathrm{mg} / 1$ and BDOC $0,5 \mathrm{mg} / \mathrm{l}$. Threshold values of the content of nonorganic nitrogen and phosphorus ions are considered as no more than $0,2 \mathrm{mgN} / 1$ and $0,01 \mathrm{mgP} / 1$ [Świderska-Bróż 2010]. Systematic research of the filtration bed has confirmed the development of microorganisms, which gradually joined in the cycle of organic matter changes. The growing number of microorganisms was proved by ATP measurements (Table 2), changes of the $\mathrm{S}$ factor (Figure 2) and microscopic observation of the bed (Photo 1 and Photo 2). Photo 1A shows the creased edge of the carbon grain, which proves the presence of biofilm (a grain without the biofilm has smooth edges). The photo $1 \mathrm{~B}$ allows to observe the biological film, washed out from the deposit. More detailed photos from a scanning microscope (Photo 2) allow to compare the porous structure of a new grain with the structure of

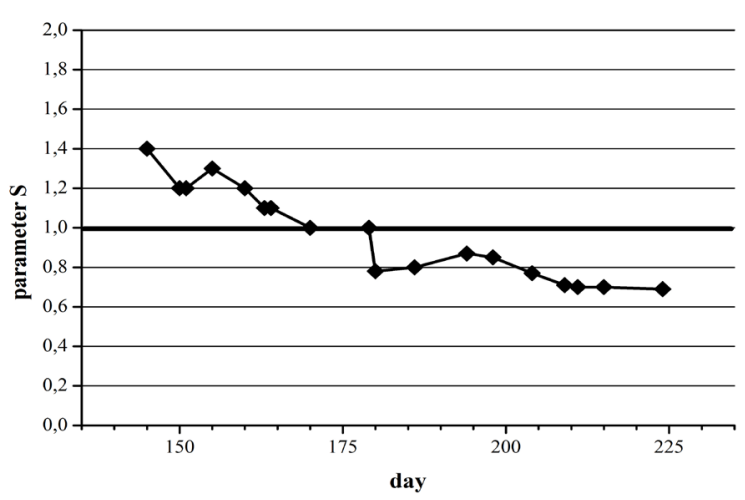

Figure 2. WD-extra Changes in $\mathrm{S}$ indicator during water filtration on WD-extra granulated active carbon

b)

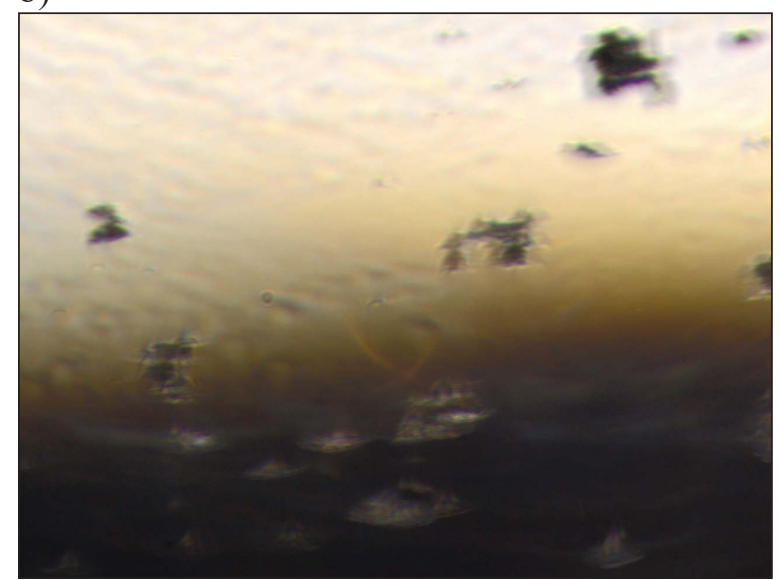

Photo 1. Biofilm (photos from light microscope): a) edge of carbon grain covered with biofilm, b) fragments of severed biofilm 
a)

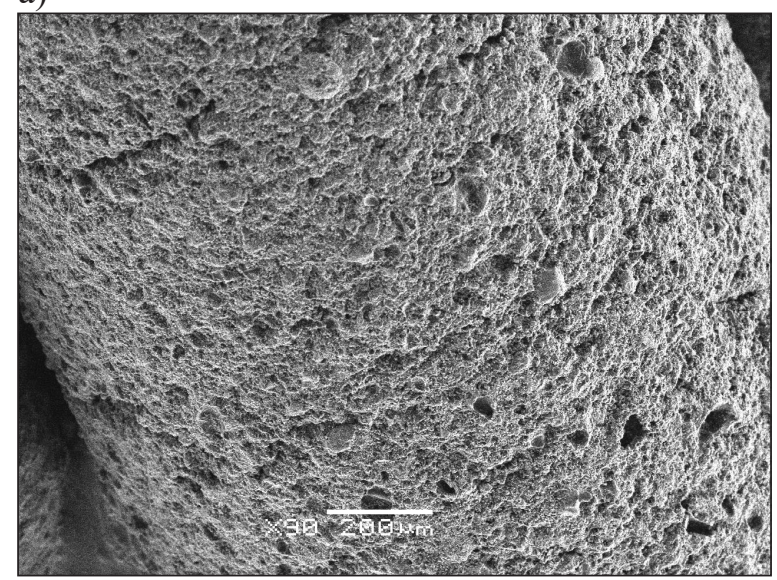

b)

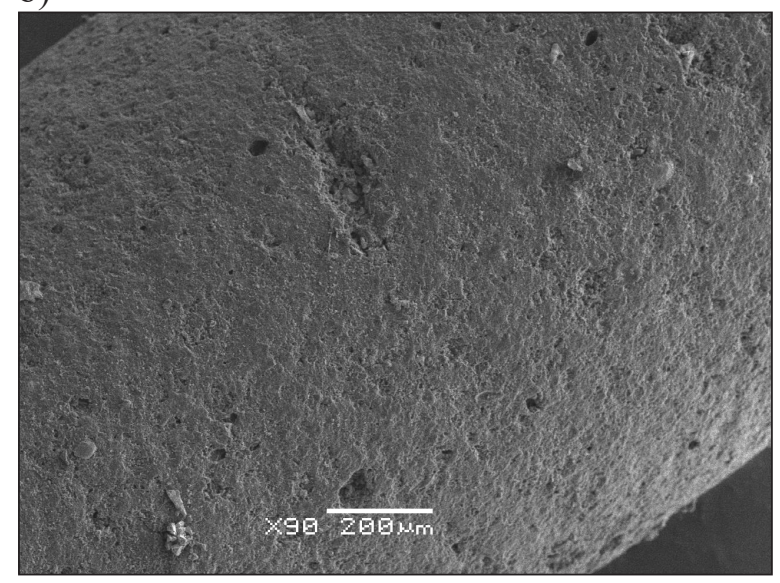

Photo 2. Grains of active carbon taken from the biofilter - photos from a scanning microscope: a) WD-extra - before biosorption, b) WD-extra carbon from biosorption bed after 8 months of operation $(\times 90)$

carbon coated by a tight biofilm. The removal of TOC in the biodegradation process additionally confirms the determined $\mathrm{S}$ indicator. Its value, since the $170^{\text {th }}$ day of filter operation, took up values lower than 1 , which indicated the domination of biodegradation over sorption (Figure 2). Biological changes are often slow, but due to the adsorption qualities of carbon, particles of organic compound may function on the coal surface for long periods of time. Along with gradual depletion of carbon sorption capacity, the microorganism biomass takes over its function, sorbing the substances present in water. The organic compounds cumulated in the biomass are used for growth and breathing. Also a systematic growth of the number of bacteria populating the biofilter filling has been observed (Table 2.). The total number of bacteria in water after the biofiltration process did not exceed $5 \mathrm{fcu} / \mathrm{ml}$. A small number of bacteria in the water after biofiltration and the fluid transition from sorption to biodegradation is a proof of well - chosen parameters for the operation of the bioactive filter. Rinsing the biofilter after 210 days of operation had no fundamental effect on its effectiveness (it was done for experimental purposes, not out of necessity). One day was enough for it to return to the level of prerinsing effectiveness. Because clean water is fed to carbon filters, containing only organic matter, frequent rinsing is not necessary. Rinsing should be done with clear, but not disinfected water, and a short term of decrease in filter effectiveness is to be expected, as a part of the active, accumulated biomass is removed along with the slops.
Table 2. Monitoring of operation of biosorption filter

\begin{tabular}{|c|c|c|c|}
\hline Day & $\begin{array}{c}\text { ATP } \\
\text { [RLU] } \\
\text { for } 1 \mathrm{~g} \text { of } \\
\text { WD-extra }\end{array}$ & $\begin{array}{c}\text { Total number of } \\
\text { bacteria } \\
\text { on } 1 \mathrm{~g} \text { of } \\
\text { WD-extra } \\
\text { [fcu/ } 1 \mathrm{~g}]\end{array}$ & $\begin{array}{c}\text { Total number } \\
\text { of bacteria in } \\
\text { water after } \\
\text { biofiltration } \\
\text { [fcu/ } 1 \mathrm{ml}]\end{array}$ \\
\hline 1 & 15 & 334 & 25 \\
\hline 23 & 22 & 488 & 4 \\
\hline 40 & 22 & 488 & 4 \\
\hline 62 & 26 & 578 & 4 \\
\hline 96 & 28 & 622 & 5 \\
\hline 108 & 30 & 666 & 5 \\
\hline 138 & 36 & 800 & 0 \\
\hline 144 & 40 & 888 & 0 \\
\hline 145 & 40 & 888 & 4 \\
\hline 150 & 41 & 910 & 0 \\
\hline 151 & 48 & 1064 & 0 \\
\hline 155 & 44 & 976 & 4 \\
\hline 160 & 59 & 1312 & 0 \\
\hline 163 & 157 & 488 & 0 \\
\hline 164 & 400 & 8888 & 4 \\
\hline 168 & 870 & 1934 & 0 \\
\hline 170 & 890 & 19778 & 4 \\
\hline 172 & 1100 & 24444 & 0 \\
\hline 179 & 3155 & 70112 & 5 \\
\hline 180 & 3012 & 66934 & 0 \\
\hline 184 & 3012 & 66934 & 0 \\
\hline 186 & 3017 & 67044 & 4 \\
\hline 190 & 3006 & 66800 & 0 \\
\hline 194 & 2907 & 64600 & 0 \\
\hline 200 & 2980 & 66222 & 0 \\
\hline 204 & 3050 & 67778 & 4 \\
\hline 206 & 3100 & 68888 & 0 \\
\hline 209 & 3100 & 68888 & 0 \\
\hline 210 & 3200 & 71112 & 0 \\
\hline 211 & 1471 & 32688 & 2 \\
\hline 218 & 2890 & 64222 & 0 \\
\hline 225 & 4565 & 101444 & 2 \\
\hline 227 & 4700 & 104444 & 0 \\
\hline 232 & 4300 & 95556 & 4 \\
\hline 240 & 4500 & 100000 & 4 \\
\hline
\end{tabular}




\section{CONCLUSIONS}

Underground water may be successfully cleansed of organic matter in a process of $2^{\text {nd }}$ degree filtration on biologically active carbon filters. Organic compounds in the purified water are $100 \%$ adsorbable and $70 \%$ biodegradable. The combination of sorption process with biodegradation, to the point of depletion of adsorption capacity of active carbon, allow for removal of about $100 \%$ of organic matter in the initial phase of carbon bed operation. The water color after biofiltration did not exceed the value of 5 Hazen. Other water parameters, like turbidity and permanganate index, were below the determination threshold. Despite the temperature of water $\left(11^{\circ} \mathrm{C}\right)$ led to the biofilter being unfavorable to develop a biofilm, fluid transition from sorption to biosorption still took place. The timely development of biofilm allowed for prolonging the filtration cycle and decreasing the TOC content by $70 \%$, that is from $10 \mathrm{mgC} / 1$ to $3-4 \mathrm{mgC} / 1$. The remaining organic carbon was non-biodegradable. It cannot be unambiguously determined how long a biologically active carbon filter will work effectively. Its time of operation is mainly influenced by the activity of microorganisms populating the bed. However, considering that we are dealing with underground water with stable chemical composition and temperature, we may risk saying that it would be a long time. Research is going to be continued.

\section{REFERENCES}

1. Aqua-tools. Monitoring of microbial contamination using ATP-metry technology. Script.

2. Kaleta J., Elektorowicz M., 2009, Removal of humic substances from aqueous solution by the coagulation process. Environmental Technology, 30(2), 119-127.

3. Kiedryńska L., 2004. Water Treatment Involving Granular Activated Carbon Filters; problem of bacterial colonization. Ochrona Środowiska /Environmental Pollution Control, 26(1), 39-42.

4. Krupińska I., 2001. Problemy związane z występowaniem substancji humusowych $\mathrm{w}$ wo- dach podziemnych. Research Bulletin of the Zielona Góra University of Technology, Environmental Engineering, No 28, 55-72.

5. Matuszewski K., Bieńkowska E., Możaryn W., 1999. Assessing the Efficiency of Full Scale GAC Filter Beds Operated at the Podolszyce Waterworks of Płock. Ochrona Środowiska/ Environmental Pollution Control, 4(75), 41-44.

6. Papciak D., Zamorska J., Kiedryńska L., 2011. Microbiology and biotechnology in the processes of water purification. The Publishing House of the Rzeszow University of Technology.

7. Papciak D., 2007. Effect Of Nitrification-Filter Packing Material On The Time To Reach Its Operation Capacity. Environmental Engineering, Taylor \& Francis Group, London, UK, 125-132.

8. Papciak D., 2013. Biofiltration of groundwaters in chalcedony beds. Instal, 10(344), 49-54.

9. Papciak D., Kaleta J., Puszkarewicz A., 2013. Removal of ammonia nitrogen from groundwater on chalcedony deposits in two-stage biofiltration process. Annual Set The Environment Protection, 15, 1352-1366.

10. Pisarek I., Głowacki M., 2015. Quality of groundwater and aquatic humic substances from main reservoire of ground water No. 333. Journal of Ecological Engineering, 16(5), 46-53.

11. Pruss A., Maciołek A., Lasocka-Gomuła I., 2009. Effect of the Biological Activity of Carbon Filter Beds of Organic Matter Removal From Water. Ochrona Środowiska /Environmental Pollution Control 4(31), 32-34.

12. Siebel E., Wang Y., Egli T., Hammes F., 2008.Correlation between total cell concentration total adenosine triphosphate concentration and heterotrophic plate counts during microbial of drinking water. Drinking Water Engineering and Science, 1, 1-6.

13. Świderska-Bróż M., 2010. Contributory Factors in the Potential of Biofilm Formation and Growth in Water Distribution Systems. Environmental Pollution Control, 32(3), 7-13.

14. Wilmański K., Gancarz J., 1997. GAC Filter Performance During Tree-Year Full-Scale Operation : a Case Study. Ochrona Środowiska /Environmental Pollution Control 4(67), 27-31.

15. Wolborska A., Zarzycki R, Cyran J., Grabowska H., Wybór M., 2003. Evaluating the Biological Activity of Carbon Filters in Surface Water Treatment: a Case Study. Ochrona Środowiska /Environmental Pollution Control, 25(4), 27-32. 